\title{
THE ADOPTION OF EXPORTS DEVELOPMENT FOR SOME NON-TRADITIONAL CROPS IN NEW LANDS IN EGYPT
}

\author{
Dalia E. Abozied ${ }^{*}$ and Soha M. Eldeep
}

Department of Economic Studies, Socio-Economic Division, Desert Research Center, El-Matareya, Cairo, Egypt

*E-mail: dalia_drc@hotmail.com

I

$\mathrm{n}$ the developing countries, many exporting farmers produce only for foreign markets. These farmers tend to be larger and more productive than domestic farmers, and often produce several products for export to many markets. In this paper, export data were examined on the non-traditional agriculture export sector in Egypt. Some non-traditional crop statues were reviewed and the possibilities of Egyptian exports development of crops were described. The data were collected and analyzed from new lands that have export crops like mint and artichokes. The estimated results indicate that the income from off-farm employment, production cost and labor have a positive effect on artichoke producers who want to become export grower. On the contrary, farm size, land quality and level of education and age have no significant effect on the artichokes reduction. On the other hand, the differences in land quality and the availability of labor significantly affect the choice of becoming an export grower. The increase in income from offfarm and production cost, decreases the likelihood that exporters will grow export crops. The age and level of education do not significantly increase the probability of becoming Mint export crop farmer.

Keywords: Egyptian exports, non-traditional crops, artichoke, medicinal and aromatic plant, adoption model

The agricultural sector is of great importance in most countries of the world, especially in developing countries. That is not only because agriculture provides food and clothing resources, but also because it contributes in supplying the industrial sector with its needs of primary materials. In addition, agriculture is an essential source for employment. Moreover, the revenue from agricultural exports plays an important role in supporting the country's economy as it is a resource of foreign currency, 
which alleviates the burden on the balance of payment and enables the country to import the needed food and industrial commodities (Al-Santarisi, 1995). Moreover, agriculture increases the capability of the society to implement economic development plans and programmes.

Crops that are not part of the customary diet of the local population and grown primarily for their high cash values and export potentials are categorized as non-traditional. Recently, several African countries have gone into the production of non-traditional fruits and vegetables of temperate origin in order to diversify their agricultural exports and increase hard currency earning. Most developed countries fall in the temperate climate zone where cropping season is limited to the summer months. On the other hand, crops can be grown throughout the year in Africa as the continent is endowed with a tropical climate. Increase in consumer demand in developed countries for out of the season fresh fruits and vegetables has opened a niche for African countries to produce these crops for export during the void period at attractive prices. Increased labor costs in developed countries have made in-season production also an attractive proposition (Singh, 2002).

Although the Egyptian agricultural sector has been for long time involved in the world markets as an exporter of various products to many countries and as importer of some necessary inputs such as tractors and pesticides. The relative importance of the Egyptian agricultural foreign trade in the world agricultural trade has been still low during the past thirty years. Fruits and vegetables are the main agricultural exports of Egypt, accounting for 57\% of total agricultural exports in 2008 (Omnia, 2010). One of the vital goals of Egypt is to develop Egyptian non-traditional exports and increase Egyptian exports competitive advantage, to reach, and to compete, in targeted market with sophisticated and enhanced products or services matching international market demand (Tabie, 2007).

Egypt has the potential to be an excellent location for non-traditional production, but the services of exports are declining as a result of many factors such as:

1. Although Egypt is one of the countries having favorable conditions for the production of aromatic plants, such as suitable environment and available low wages work force, the cultivated area of these plants is not satisfactory.

2. Lack of marketing information management.

3. Lack of coordination among exporters.

4. Lack of funding for research and development.

Some farms now adopt techniques to their production of many species of non-traditional crops, such as artichokes and mint, mainly in the newly reclaimed areas. The present study concentrated on possibilities of Egyptian exports development of some non-traditional crops in the new lands to increase the cultivated area for export in Egypt facing the increasing demand both in Egypt and abroad, for its multiple uses, but this objective

Egyptian J. Desert Res., 62/63, 87-96 (2012/2013) 
does not mean that non-traditional crops would replace the major traditional crops.

While artichoke is one of the promising, non-traditional and exportable vegetable crops in Egypt, and it is cultivated in Egypt mainly for export, the major part of production can not be exported and remain in the local markets. From this point, this study focused on artichoke market and explored the factors that may help to increase the exports of Egyptian artichokes in the importer markets.

The medicinal and aromatic plants are considered one of the most important non-traditional agricultural commodities, which can be used as a base for Egyptian national income development, where it obtained increasing demand of domestic and foreign markets (Ahmed, 1980). This study concentrated on mint as one of important medicinal and aromatic plants in Egypt.

\section{MATERIALS AND METHODS}

The study based on two sources of data, primary data generated through a sample survey covering new lands, collected from 240 exporters that have been randomly selected non-traditional crop producers, including the input and output data. The secondary data depended on published details from the Egyptian Ministry of Agriculture and Land Reclamation, Economic Affairs Sector, Administration for Agricultural Economic, UN Comrade Information.

A model was developed that can be used in developing new export products (and markets) in case there is an increasing foreign demand. The model can explain many features of the data. The theoretical concept of the model application is income potentially earned off-farm determines the opportunity cost of working on farm, farm size, land quality, relatively secure off-farm employment. It should be access to alternative, relatively secure off-farm income source entering here as exogenous factors, since high substitution of daily wage earning and occasional trading income versus onfarm work in the new export crop prevails. On the other hand, labor force and women's share may be affecting factor for adoption. The access of region to infrastructure affects adoption of the new crops. Based on these hypotheses, the adopted model uses the logical discrete binary regression model (Maddala, 1983 and Amemiya, 1985).

The model assumes an underling latent adoption variable $\mathrm{y}_{\mathrm{i}}{ }_{\mathrm{i}}$ defined by the relationship:

$\mathbf{Y}^{*}{ }_{\mathbf{i}}=\boldsymbol{\beta}^{\prime} \mathbf{X}_{\mathrm{ik}}+\mathbf{u}_{\mathbf{i}} \quad$ where $\mathbf{u}_{\mathrm{i}}$ is assumed in $\left(0, \sigma^{2}\right)$. However, in practice $\mathrm{y}$ is defined by $\mathrm{y}_{\mathrm{i}}=1$, if $\mathrm{y}_{\mathrm{i}}{ }_{\mathrm{i}}>0, \mathrm{y}=0$ otherwise.

The adoption model focused on the determinants of the exports development for some non-traditional crops specified as follows (Von Braum, 1989):

Egyptian J. Desert Res., 62/63, 87-96 (2012/2013) 


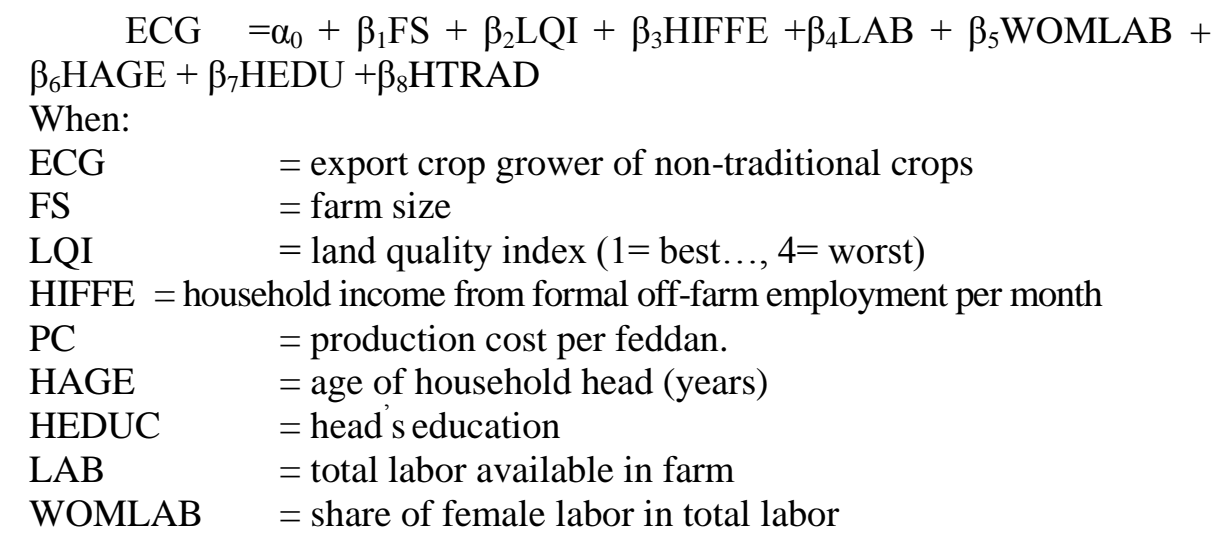

\section{RESULTS AND DISCUSSION}

The development of economic variables of total export value and total export value of vegetables, medicinal and aromatic plants, artichokes and mint in Egypt through the period (2000-2008) were studied. Statistical estimation for trend equations was also used for these variables. Table (1) shows the total export in Egypt during the years from 2000 to 2008. The total export showed an increasing trend from year to another with maximum of 24 million US \$ (2008) and a minimum of 4164.9 million US \$ (2001) with an average of 10.2 million US $\$$ during the investigated years.

Table (1). The development of economic variables of total export value and total export value of vegetables, medicinal and aromatic, artichokes and mint in Egypt through 2000-2008.

\begin{tabular}{llllll}
\hline Years & $\begin{array}{c}\text { Total export } \\
\text { (million US } \\
\mathbf{\$} \text { ) }\end{array}$ & $\begin{array}{c}\text { Vegetables } \\
\text { export } \\
\text { (million US } \\
\mathbf{\$} \text { ) }\end{array}$ & $\begin{array}{c}\text { Medicinal and } \\
\text { aromatic plants } \\
\text { export } \\
\text { (million US \$) }\end{array}$ & $\begin{array}{c}\text { Artichoke } \\
\text { export } \\
\text { (million } \\
\text { US \$) }\end{array}$ & $\begin{array}{c}\text { Mint } \\
\text { export } \\
\text { (US \$) }\end{array}$ \\
\hline 2000 & 4712.9 & 3.723 & 3.541 & 1.012 & 0.120 \\
2001 & 4164.9 & 5.217 & 6.701 & 0.820 & 0.422 \\
2002 & 4691.6 & 6.947 & 7.460 & 0.888 & 0.191 \\
2003 & 6160.7 & 6.259 & 5.207 & 0.902 & 0.258 \\
2004 & 7912.8 & 22.808 & 2.868 & 1.840 & 0.31 \\
2005 & 10647.03 & 22.733 & 8.297 & 2.016 & 0.115 \\
2006 & 13756.3 & 37.140 & 5.755 & 1.060 & 0.33 \\
2007 & 16100.6 & 39.343 & 1.599 & 1.634 & 0.46 \\
2008 & 23994.7 & 105.925 & 2.979 & 5.508 & 0.348 \\
Average & 10237.9 & 27.788 & 4.93 & 1.742 & 0.284 \\
\hline Source: www.UNcomtrade.com & & &
\end{tabular}

On the other hand, the vegetable export showed an increase from one season to another with a maximum value of 105.925 million US \$ (2008) and a minimum value of 3.723 million US \$ (2000), with an average of 27.788 million US \$ during the study period. Also, medicinal and

Egyptian J. Desert Res., 62/63, 87-96 (2012/2013) 
aromatic plants export showed an increase from year to another with a maximum value of 8.297 million US \$ (2005) and a minimum value of 1.599 million US \$ (2007) with an average of 4.93 million US \$ during the study period. Moreover the artichokes export in Egypt showed an increasing trend in the same period with a maximum of 5.508 million US \$ (2008) and a minimum of 0.820 million US \$ (2001) with an average of 1.742 million US $\$$ during the investigated years. On the other side, for mint export, its maximum value was 0.46 million US \$ (2007) and minimum value was 0.115 million US \$ (2005) with an average of 0.284 million US \$ during the same period.

Summary statistics of estimated associated coefficients of time trend are presented in table (2). It can be seen that (i) all the estimated parameters in equations 1, 2 and 4 are statistically significant, (ii) all equations estimated coefficients of time trend were positive and significant implying that all export and total export of all types were increasing; (iii) the parameters of equations 3 and 5 are not statistically significant.

Table (2). Trend equations for total export value \& total export value of Vegetables, medicinal and Aromatic plants, Artichokes, Mint in Egypt during the period (2000-2008).

\begin{tabular}{|c|c|c|c|c|c|}
\hline $\begin{array}{c}\text { Equation } \\
\text { No. } \\
\end{array}$ & Equation & $\mathbf{R}^{2}$ & Mean & $\mathbf{F}$ & $\begin{array}{c}\text { Dependent } \\
\text { variable }(y)\end{array}$ \\
\hline 1 & $\begin{array}{c}Y=2000.4+0.00034 X \\
(2672.2)^{* *}(5.7)^{* *}\end{array}$ & 0.82 & 10485.63 & 32.78 & Total export \\
\hline 2 & $\begin{array}{c}Y=2002.04+0.0703 X \\
(2719.1)^{* *}(3.9)^{* *}\end{array}$ & 0.68 & 27.8 & 15.5 & $\begin{array}{l}\text { Vegetables } \\
\text { export }\end{array}$ \\
\hline 3 & $\begin{array}{c}Y=2006.1-0.418 X \\
(889.4)^{* *}(5.7)^{* *}\end{array}$ & 0.12 & 4.93 & 0.99 & $\begin{array}{l}\text { Medicinal } \\
\text { and aromatic } \\
\text { plants export }\end{array}$ \\
\hline 4 & $\begin{array}{c}Y=2001.8+1.246 X \\
(1737)^{* *}(2.41)^{* *}\end{array}$ & 0.45 & 1.74 & 5.83 & $\begin{array}{l}\text { Artichoke } \\
\text { export }\end{array}$ \\
\hline 5 & $\begin{array}{c}Y=2001.3+9.541 \mathrm{X} \\
(861.1)^{* *}(1.25)\end{array}$ & 0.18 & 0.28 & 1.58 & Mint export \\
\hline $\begin{array}{l}\text { Source: col } \\
\text { Where: } \\
\mathrm{Y}_{\mathrm{t}}=\text { Estim } \\
\mathrm{Xt}=\text { time } \mathrm{v} \\
\text { Numbers } \mathrm{b}\end{array}$ & $\begin{array}{l}\text { ated from table (1) } \\
\text { value of the dependent var } \\
\text { able of the year } t \text {, where, } t= \\
\text { seen brackets indicate " } t \text { " va }\end{array}$ & $\begin{array}{l}t \text { the } \\
4,5\end{array}$ & .9 year & & \\
\hline
\end{tabular}

The collected data for mint crop show personal and socio-economic characteristics. Majority of $66.5 \%$ had their farm size between 2 and 5 feddan. About $33.5 \%$ had farm size between 1 and 1.5 feddan. Majority of $60.9 \%$ of the age of household head of $37-47$ years, $39.1 \%$ were 55 years 
and above. About 35\% of household head had university completed, $31.7 \%$ had secondary school education, while $21.9 \%$ of household head had primary education and $11.4 \%$ had no education at all.

The collected data for artichokes crop show personal and socioeconomic characteristics. The majority of $63.4 \%$ had their farm size between 4 to 6 feddan. About $36.6 \%$ had farm sizes between 7.5 and 9 feddan. The majority of $53.6 \%$ of the age of household head of 42 and 50 years, $46.4 \%$ were 52 years and above. About $38.6 \%$ of household head had university completed, $27.2 \%$ had secondary school education, while $31.8 \%$ of household head had primary education and $2.4 \%$ had no education at all.

\section{Probit Estimate of Export Crop Adoption}

The estimation results indicate that the decision of exporter to adopt the two types of export crops, are as follows:

First: Artichokes crop: according to analysis results in table (3):

1. Increased income from off-farm employment that relatively secures income from sources other than day labor, increases the likelihood that exporters will grow export crops.

2. Although the production cost in the sample is big by almost any standard, an increase in production cost significantly increases the probability of becoming export grower.

3. Availability of labor significantly affects the choice of becoming an export grower and the market for hired labor is highly integrated in the region, which suggests this model outcome.

Table (3). Probit estimate of artichoke export crop adoption.

\begin{tabular}{ccccc}
\hline $\begin{array}{c}\text { Independent } \\
\text { variable }\end{array}$ & Coefficient & Z-valve & $\begin{array}{c}\text { Mean value } \\
\text { of variable }\end{array}$ & Standard deviation \\
\hline FS & 0.91760 & 0.813 & 6.500 & 1.546 \\
LQI & -0.55930 & -0.300 & 2.600 & 0.570 \\
HIFFE & 0.00470 & 1.990 & 1203.488 & 550.360 \\
PC & 0.04322 & 2.340 & 2091.860 & 348.280 \\
HAGE & 0.07740 & 0.460 & 49.650 & 5.927 \\
HEDUC & -0.83790 & -0.430 & 3.060 & 0.856 \\
LAB & -18.79510 & -2.270 & 4.950 & 0.990 \\
\hline
\end{tabular}

Source: compiled and estimated by authors from questionnaire.

The statistically insignificant results in the probit model are also interesting to note:

1. An increase of farm size does not significantly increase the probability of becoming an export crop farmer.

2. Differences in land quality of the farm have not significantly affected the choice of becoming a crop exporter.

3. The age and level of education of household head, which were assumed in order to indicate human capital endowment of the household, do not significantly, affect the adoption probability.

Egyptian J. Desert Res., 62/63, 87-96 (2012/2013) 
Table (4). Probit estimate of Mint export crop adoption.

\begin{tabular}{ccccc}
\hline $\begin{array}{c}\text { Independent } \\
\text { variable }\end{array}$ & Coefficient & Z-valve & $\begin{array}{c}\text { Mean value } \\
\text { of variable }\end{array}$ & $\begin{array}{c}\text { Standard } \\
\text { deviation }\end{array}$ \\
\hline FS & 1.4780 & 1.09 & 1.710 & 0.439 \\
LQI & 1.3040 & 1.82 & 2.102 & 0.880 \\
HIFFE & -0.0018 & -1.95 & 1198.720 & 578.390 \\
PC & -0.0037 & -1.81 & 1410.256 & 458.139 \\
HAGE & 0.1408 & 1.70 & 49.640 & 8.418 \\
HEDUC & 0.6246 & 1.03 & 2.970 & 0.959 \\
LAB & 4.6390 & 2.52 & 2.460 & 0.600 \\
\hline
\end{tabular}

Source: compiled and estimated by authors from questionnaire

Second: Mint crop: according to analysis results in table (4):

1. Differences in land quality of the farm have significantly affected the choice of becoming an export crop farmer.

2. Increased income from off-farm employment, that relatively secure income from sources other than day labor, decreases the likelihood that exporters will grow export crops.

3. An increase of production cost significantly decreases the probability of becoming export grower.

4. Availability of labor significantly affects the choice of becoming an export grower.

The statistically insignificant results in the probit model are also interesting to note:

1. The farm size does not significantly increase the probability of becoming an export crop farmer

2. The age and level of education of household head, which were assumed in order to indicate human capital endowment of the household, do not significantly affect the adoption probability.

\section{. SUMMARY AND CONCLUSION}

Favorable climatic conditions, together with the suitability of soil and the availability of inputs have encouraged the cultivation of a variety of field crops, vegetables and fruits. Population increase, reflectied in an increasing demand of these crops, has stimulated the growers to expand their production of food crops. Moreover, the relative advantage that some Egyptian crops take at the international trade level was also a factor strongly stimulating the expansion of production in order to cover Egypt's share in this trade. The obvious variation in the cultivated area and the production size of the different crops reflect, on one hand, the consumption preference 
and, on the other, the agricultural pricing policy and the world prices for some crops.

This paper aimed to study the possibilities of Egyptian exports development of some non-traditional crops such as artichokes and mint. The results indicate that the income from off-farm employment, production cost and labor have a positive effect on artichokes producers, who want to be becoming export grower. On the contrary, farm size, land quality and level of education and age have not significantly affected them. On the other hand, the differences in land quality and availability of labor significantly affect the choice of becoming an exporter, but increased income from off-farm and production cost, decreases the likelihood that exporters will grow export crops. The age and level of education do not significantly increase the probability of becoming mint export crop farmer.

Although the Egyptian export crops encounter a high competition in the import markets, it still has a valuable potentiality to increase the exports in import markets. So, if Egypt manages to reduce the costs of transport and related logistics services by establishing highly efficient ports and a competitive shipping services industry, the cost-competitiveness of its fruit and vegetable supply would improve. By enhancing the efficiency of transport and related logistics services, Egypt could become an important Southern Mediterranean Country (SMC) player in the logistical organization and in distributing fresh and processed fruits and vegetables to the world market. In addition, Egypt needs to develop marketing processes through joining the international food chains and large-scale retail trade.

\section{REFERENCES}

Ahmed, S.E. (1980). An Analytical Study for the expansion possibilities in producing and marketing the aromatic plants products, M.Sc., Agricultural Economic Dept., Faculty of Agriculture, El-Azhar University.

Al-Santarisi, M. (1995). The Future of Egyptian Agriculture in International Trade, Faculty of Agriculture, Ain Shams University, Cairo.

Amemiya, T. (1985). In "Advanced Econometrics". Harvard University Press, Cambridge, 521 pp.

Egyptian Ministry of Agriculture and Land Reclamation, Economic Affairs sector, Agriculture Economics Bulletin (2008).

Maddala, G.S. (1983). In "Limited-dependent and Qualitative Variables in Econometrics". Cambridge University Press, Cambridge, 401 pp.

Omnia Helmy (2010). Competitiveness of Egypt in the EU Market for Fruit and Vegetables, Working Paper No. 154, Egyptian Center for Economic Studies, March 2010.

Egyptian J. Desert Res., 62/63, 87-96 (2012/2013) 
Singh, B.P. (2002). In "Non-traditional Crop Production in Africa for Export, Trends in New Crops and New Uses". (Janick J. and A. Whipkey, eds.). ASHS Press, Alexandria, VA.

Tabie, M. (2007). Analysis of export demand for Egyptian artichokes, African Crops Science Conference Proceeding, 8: 1265-1270.

Von Braum, J. (1989). Non-traditional export crops in Guatemala: effects on production, income, and nutrition. Research report 73, International Food Policy Research Institute in Collaboration with the Institute of Nutrition of Central America and Panama, May. 


\title{
تبني تنمية الصادرات لبصض الحاصلات غير التقليدية في الأراضي الجديدة في مصر
}

\author{
داليا السيد أبوزيد" وسها مصطقى الايب الإزاب \\ قسم الدراسات الإقتصادية، شعبة الإدية الدراسات الإقتصادية والإجتماعية، مركز بحوث \\ الصحر اء، المطرية، القاهرة، مصر الأهرة
}

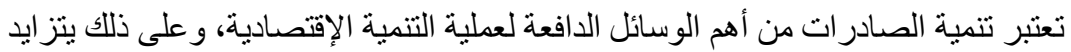

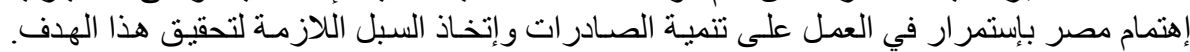

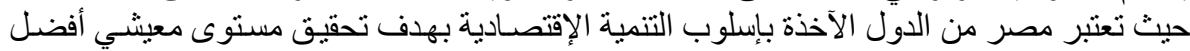

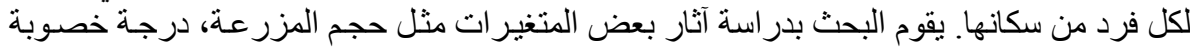

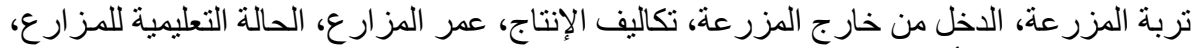

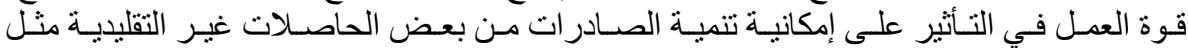

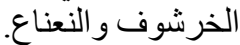

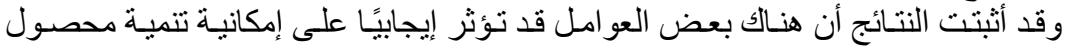

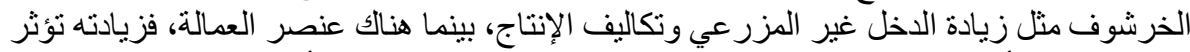

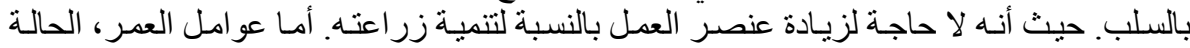

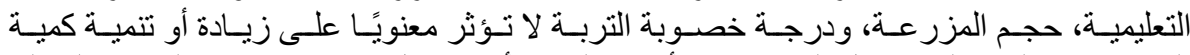

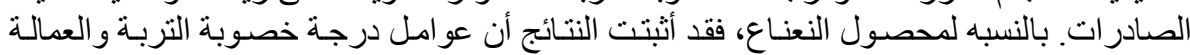

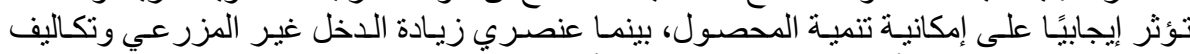

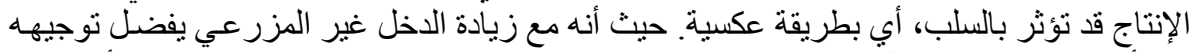

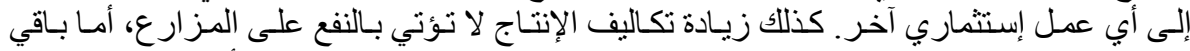

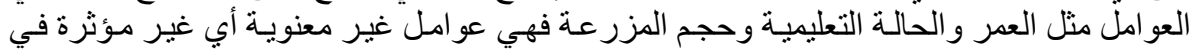

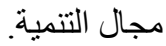

Egyptian J. Desert Res., 62/63, 87-96 (2012/2013) 
